University of Nebraska - Lincoln

DigitalCommons@University of Nebraska - Lincoln

Faculty Publications: Department of

Entomology

Entomology, Department of

2007

\title{
Substitution of conserved cysteine residues in wheat streak mosaic virus HC-Pro abolishes virus transmission by the wheat curl mite
}

\author{
B. A. Young \\ USDA-ARS, University of Nebraska-Lincoln
}

Gary L. Hein

University of Nebraska-Lincoln, ghein1@unl.edu

Roy C, French

USDA-ARS, University of Nebraska-Lincoln, rfrench2@unl.edu

Drake C. Stenger

USDA-ARS, San Joaquin Valley Agricultural Sciences Center, dstenger@fresno.ars.usda.gov

Follow this and additional works at: https://digitalcommons.unl.edu/entomologyfacpub

Part of the Entomology Commons

Young, B. A.; Hein, Gary L.; French, Roy C; and Stenger, Drake C., "Substitution of conserved cysteine residues in wheat streak mosaic virus HC-Pro abolishes virus transmission by the wheat curl mite" (2007). Faculty Publications: Department of Entomology. 255.

https://digitalcommons.unl.edu/entomologyfacpub/255

This Article is brought to you for free and open access by the Entomology, Department of at DigitalCommons@University of Nebraska - Lincoln. It has been accepted for inclusion in Faculty Publications: Department of Entomology by an authorized administrator of DigitalCommons@University of Nebraska - Lincoln. 


\title{
Substitution of conserved cysteine residues in wheat streak mosaic virus HC-Pro abolishes virus transmission by the wheat curl mite
}

\author{
B. A. Young ${ }^{1}$, G. L. Hein ${ }^{2}$, R. French ${ }^{1}$, D. C. Stenger ${ }^{1}$ \\ ${ }^{1}$ United States Department of Agriculture - Agricultural Research Service and Department of Plant Pathology, \\ University of Nebraska, Lincoln, NE, USA \\ ${ }^{2}$ Department of Entomology, University of Nebraska Panhandle Research Center, Scottsbluff, NE, USA
}

Received 7 May 2007; Accepted 14 June 2007; Published online 7 August 2007

(C) Springer-Verlag 2007

\begin{abstract}
Summary
Substitutions in the amino-proximal region of wheat streak mosaic virus (WSMV) HC-Pro were evaluated for effects on transmission by the wheat curl mite (Aceria tosichella Keifer). Alanine substitution at cysteine residues 16, 46 and 49 abolished vector transmission. Although alanine substitution at $\mathrm{Cys}_{20}$ had no effect, substitution with arginine reduced vector transmission efficiency. Random substitutions at other positions ( $\mathrm{Lys}_{7}$ to Asn, $\mathrm{Asn}_{19}$ to Ile, and $\operatorname{Arg}_{45}$ to Lys) did not affect vector transmission. These results suggest that a zinc-fingerlike motif $\left(\mathrm{His}_{13}-\mathrm{X} 2-\mathrm{Cys}_{16}-\mathrm{X} 29-\mathrm{Cys}_{46}-\mathrm{X} 2-\mathrm{Cys}_{49}\right)$ in WSMV HC-Pro is essential for vector transmission.
\end{abstract}

Wheat streak mosaic virus (WSMV) is the type species of the genus Tritimovirus in the family Potyviridae [15]. Whereas viruses of the genus

Correspondence: Drake C. Stenger, USDA-ARS, San Joaquin Valley Agricultural Sciences Center, 9611 South Riverbend Avenue, Parlier, CA 93648, USA e-mail: dstenger@fresno.ars.usda.gov
Potyvirus are transmitted non-persistently by aphids, WSMV is transmitted semi-persistently by the wheat curl mite (Aceria tosichella Keifer). Both tritimoviruses $[14,17]$ and potyviruses [7, 19] encode HC-Pro homologues required for vector transmission. Although HC-Pro sequence conservation among the two genera is limited [6], functional domains of WSMV HC-Pro [16, 18] involved in vector transmission (amino-proximal) and polyprotein maturation (carboxy-proximal) are positioned similarly to that of potyvirus HC-Pro.

Alignment of WSMV HC-Pro with potyvirus HC-Pro is mostly ambiguous except for the proteinase domain in the carboxy-proximal third of the protein [6]. Nonetheless, the amino-proximal region of both potyvirus and tritimovirus HC-Pro are cysteine-rich. HC-Pro of both genera self-interact $[5,8,11,20]$; mutations introduced into the cysteine-rich region of potyvirus HC-Pro have been shown to abolish self interaction [20] and aphid transmission [1, 2, 9]. Whether amino acid substitutions in the corresponding region of WSMV HC-Pro affect virus transmission by the wheat curl mite is unknown. Here, we address this issue by evaluating infectivity and vector transmission phe- 
notypes of WSMV bearing amino acid substitutions in the amino-proximal region of HC-Pro.

An infectious cDNA clone of the WSMV Sidney 81 isolate was constructed previously [4] and subsequently modified [12] to contain unique SalI and ApaI sites (pS81-SA) flanking the HC-Pro coding region. This SalI-ApaI fragment was subcloned into pALTER (Promega, Madison, WI) and served as a template for site-directed mutagenesis. Codons for each of four cysteine residues $\left(\mathrm{Cys}_{16}, \mathrm{Cys}_{20}\right.$, $\mathrm{Cys}_{46}$, and $\mathrm{Cys}_{49}$ ) in the $5^{\prime}$-proximal coding region of WSMV HC-Pro were mutated individually to alanine codons. Site-directed mutagenesis also was used to generate double mutants in which pairs of cysteine codons $\left(\mathrm{Cys}_{16}+\mathrm{Cys}_{20}\right.$ and $\mathrm{Cys}_{46}+$ $\mathrm{Cys}_{49}$ ) were altered to alanine codons in the same construct. Primers (sequences in WSMV minus strand) used for site-directed mutagenesis (underline denotes nucleotide substitutions) were $5^{\prime}$-TTG CGCAGTTGTTGTTGGCCACATCGTGATATTT CGG-3' (Cys 16 to Ala), 5'-CAGGTAACTTGCTGC GTTGTTGTTGCACA-3' (- Cys $_{20}$ to Ala), 5'-GTTC TACATTGGTCTGCCCTCAGATTATG- $3^{\prime} \quad$ (Cys $_{46}$ to Ala), 5'-CCACTCTGTTCTTGCTTGGTCGCA CCTC-3' $\left(\mathrm{Cys}_{49}\right.$ to Ala), 5'-TCCAGGTAACTTGC TGCGTTGTTGTTTGCCACATCGTGATATTTC$3^{\prime}$ (Cys 16 to Ala and $\mathrm{Cys}_{20}$ to Ala), and 5'-TTCC ACTCTGTTCTTGCTTGGTCTGCCCTCAGATT ATGTA-3' (Cys 46 to Ala and $\mathrm{Cys}_{49}$ to Ala). The four single and two double mutations were verified by nucleotide sequencing. Each mutant SalI-ApaI fragment was excised from the pALTER derivatives and subsequently used to replace the SalI-ApaI fragment of pS81-SA. RNA was transcribed from each mutant construct and inoculated to wheat seedlings (cv. Arapahoe) essentially as described [4]. Transcripts from all six mutant constructs were infectious to wheat and generated wild-type systemic symptoms (Table 1). The infection status of transcript-inoculated plants was verified by reverse transcription-polymerase chain reaction (RT-PCR) of the HC-Pro region as described [12]. The stability of mutations introduced into WSMV HC-Pro was assessed by sequencing of plasmids bearing cloned inserts of RT-PCR products amplified from systemically infected test plants. No evidence for reversion was seen; all cysteine-to-alanine substitu-
Table 1. Infectivity of wheat streak mosaic virus with cysteine-to-alanine substitutions in HC-Pro

\begin{tabular}{|c|c|c|c|c|}
\hline \multirow{2}{*}{$\begin{array}{l}\text { WSMV } \\
\text { genotype }^{\text {a }}\end{array}$} & \multicolumn{2}{|c|}{ Experiment $1^{\mathrm{b}}$} & \multicolumn{2}{|c|}{ Experiment $2^{\mathrm{b}}$} \\
\hline & Symptoms & $\begin{array}{l}\text { RT- } \\
\text { PCR }\end{array}$ & Symptoms & $\begin{array}{l}\text { RT- } \\
\text { PCR }\end{array}$ \\
\hline $\mathrm{Cys}_{16}$ to Ala & $10 / 10$ & $10 / 10$ & $9 / 10$ & $4 / 4$ \\
\hline $\mathrm{Cys}_{20}$ to Ala & $10 / 10$ & $10 / 10$ & $10 / 10$ & $4 / 4$ \\
\hline $\begin{array}{l}\mathrm{Cys}_{16} \text { to } \mathrm{Ala}+ \\
\mathrm{Cys}_{20} \text { to Ala }\end{array}$ & $7 / 10$ & $7 / 10$ & $10 / 10$ & $4 / 4$ \\
\hline $\mathrm{Cys}_{45}$ to Ala & $7 / 10$ & $9 / 10$ & $8 / 10$ & $4 / 4$ \\
\hline $\mathrm{Cys}_{49}$ to Ala & $9 / 10$ & $10 / 10$ & $9 / 10$ & $4 / 4$ \\
\hline $\begin{array}{l}\mathrm{Cys}_{45} \text { to Ala }+ \\
\mathrm{Cys}_{49} \text { to Ala }\end{array}$ & $8 / 10$ & $9 / 10$ & $9 / 10$ & $4 / 4$ \\
\hline No virus control & $0 / 10$ & $0 / 4$ & $0 / 10$ & $0 / 4$ \\
\hline
\end{tabular}

a Subscript denotes HC-Pro amino acid coordinate. Stability of mutations verified by sequencing of RT-PCR products cloned from systemically infected wheat plants.

b Number of plants infected/number of inoculated plants evaluated. Infection status of plants determined by visual inspection for symptoms and by RT-PCR.

tions were retained by WSMV in systemically infected plants (data not shown).

Previously, a series of 35 randomly generated point mutations in WSMV HC-Pro were evaluated for systemic infectivity, the ability to generate primary infection foci, and autoproteolytic activity [18]. Among the random mutations analyzed, four nonsynonymous point substitutions ( $\mathrm{Lys}_{7}$ to Asn, $\mathrm{Asn}_{19}$ to Ile, $\mathrm{Cys}_{20}$ to $\mathrm{Arg}$, and $\mathrm{Arg}_{45}$ to Lys) that occurred within the amino-proximal region of WSMV HCPro had no effect on pathogenicity or proteinase activity. These four randomly generated mutations, along with the cysteine-to-alanine site-directed mutations described above, were evaluated for phenotypic effects on virus transmission by the wheat curl mite.

Wheat curl mite transmission assays were conducted essentially as described [17]. Wheat seedlings to be used as source plants for vector transmission assays were inoculated with transcripts derived from each of the ten mutant constructs. Wheat seedlings inoculated with transcripts of pS81-SA or non-inoculated wheat seedlings served as positive or negative (mock) control source plants, respectively. Total RNA was extracted [10] from leaf samples 12-14 days post inoculation and used as template to determine infection status of source 
Table 2. Vector transmission of wheat streak mosaic virus (WSMV) mutants bearing amino acid substitutions in HC-Pro

\begin{tabular}{|c|c|c|c|c|c|c|c|}
\hline \multirow{4}{*}{ WSMV Genotype } & \multicolumn{7}{|c|}{ Transmission to test plants ${ }^{\mathrm{a}}$} \\
\hline & \multicolumn{7}{|c|}{ Acquisition source plant } \\
\hline & \multicolumn{3}{|c|}{ Experiment 1} & \multicolumn{3}{|c|}{ Experiment 2} & \multirow[t]{2}{*}{$\mathrm{All}^{\mathrm{c}}$} \\
\hline & A & $\mathrm{B}$ & $\mathrm{C}$ & $\mathrm{D}$ & $\mathrm{E}$ & $\mathrm{F}$ & \\
\hline $\mathrm{Cys}_{16}$ to Ala & $0 / 4$ & $0 / 4$ & $0 / 4$ & $0 / 4$ & $0 / 4$ & $\mathrm{ND}^{\mathrm{b}}$ & $0 / 20(0 \%)$ \\
\hline $\mathrm{Cys}_{20}$ to Ala & $3 / 4$ & $3 / 4$ & $4 / 4$ & $3 / 4$ & $3 / 4$ & $4 / 4$ & $20 / 24(83 \%)^{*}$ \\
\hline $\begin{array}{l}\mathrm{Cys}_{16} \text { to Ala \& } \\
\mathrm{Cys}_{20} \text { to Ala }\end{array}$ & $0 / 4$ & $0 / 4$ & $0 / 4$ & $0 / 4$ & $0 / 4$ & $\mathrm{ND}^{\mathrm{b}}$ & $0 / 20(0 \%)$ \\
\hline $\mathrm{Cys}_{46}$ to Ala & $0 / 4$ & $0 / 4$ & $0 / 4$ & $0 / 4$ & $0 / 4$ & $\mathrm{ND}^{\mathrm{b}}$ & $0 / 20(0 \%)$ \\
\hline $\mathrm{Cys}_{49}$ to Ala & $0 / 4$ & $0 / 4$ & $0 / 4$ & $0 / 4$ & $0 / 4$ & $0 / 4$ & $0 / 24(0 \%)$ \\
\hline $\begin{array}{l}\mathrm{Cys}_{46} \text { to Ala \& } \\
\mathrm{Cys}_{49} \text { to Ala }\end{array}$ & $0 / 4$ & $0 / 4$ & $0 / 4$ & $0 / 4$ & $0 / 4$ & $0 / 4$ & $0 / 24(0 \%)$ \\
\hline $\mathrm{Lys}_{7}$ to Asn & $4 / 4$ & $4 / 4$ & $3 / 4$ & $3 / 4$ & $3 / 4$ & $2 / 4$ & $19 / 24(79 \%)^{*}$ \\
\hline $\mathrm{Asn}_{19}$ to Ile & $4 / 4$ & $4 / 4$ & $4 / 4$ & $2 / 4$ & $2 / 4$ & $4 / 4$ & $20 / 24(83 \%)^{*}$ \\
\hline $\mathrm{Cys}_{20}$ to $\mathrm{Arg}$ & $0 / 4$ & $3 / 4$ & $1 / 4$ & $0 / 4$ & $0 / 4$ & $0 / 4$ & $4 / 24(17 \%)$ \\
\hline $\mathrm{Arg}_{45}$ to Lys & $4 / 4$ & $4 / 4$ & $4 / 4$ & $1 / 4$ & $3 / 4$ & $4 / 4$ & $20 / 24(83 \%)^{*}$ \\
\hline Wild type (S81-SA) & $3 / 4$ & $4 / 4$ & $3 / 4$ & $4 / 4$ & $4 / 4$ & $3 / 4$ & $21 / 24(87 \%)^{*}$ \\
\hline No virus (mock) & $0 / 4$ & $0 / 4$ & $0 / 4$ & $0 / 4$ & $0 / 4$ & $0 / 4$ & $0 / 24(0 \%)$ \\
\hline
\end{tabular}

a Number of test plants infected/number test plants inoculated.

b $N D$ Not determined.

c Asterisk denotes vector transmission efficiency not significantly different $(P>0.05)$ from wild type (S81-SA) based on ANOVA and Tukey's multiple comparison tests.

plants by RT-PCR as described [12]. The presence of each mutation was verified by sequencing of one RT-PCR product per mutant per experimental replicate (data not shown). Source plants (three per mutant per experimental replicate, except as noted in Table 2) were each colonized with ten wheat curl mites transferred from an aviruliferous colony. After a three-week acquisition access period, wheat curl mite progeny were transferred in groups of ten from each source plant to healthy wheat seedlings serving as test plants (four per source plant). Following a four-week inoculation access period, test plants were harvested and leaves stored at $-80^{\circ} \mathrm{C}$. To prevent movement of wheat curl mites among plants, each source plant and each test plant was individually caged. The infection status of each test plant was determined by RT-PCR as described above.

Results of the wheat curl mite transmission assays are presented in Table 2. Of the four single cysteine-to-alanine substitutions, the only mutant that retained vector transmission competence was $\mathrm{Cys}_{20}$ to Ala. The remaining three single substitution mutants and the two WSMV genomes bear- ing double cysteine-to-alanine mutations were not transmitted by the wheat curl mite. Three of the four randomly generated substitution mutants $\left(\mathrm{Lys}_{7}\right.$ to Asn, $\mathrm{Asn}_{19}$ to Ile, and $\mathrm{Arg}_{45}$ to Lys) were transmitted by the wheat curl mite at levels (79-83\%) similar to that of the positive control S81-SA $(87 \%)$. The mutant bearing the $\mathrm{Cys}_{20}$-to-Arg substitution retained vector transmission competence, albeit at a reduced level (17\%) compared to S81$\mathrm{SA}$ or the alanine substitution mutant at $\mathrm{Cys}_{20}$ $(83 \%)$. All test plants colonized with wheat curl mites transferred from uninoculated (mock) source plants tested negative for WSMV infection by RTPCR. Direct sequencing of RT-PCR products (two per mutant construct) amplified from WSMVinfected test plants revealed no evidence for reversion (data not shown) following transmission by the wheat curl mite.

We propose that the amino-proximal region of WSMV HC-Pro contains a non-canonical zinc finger motif [3] ( $\left.\mathrm{His}_{13}-\mathrm{X} 2-\mathrm{Cys}_{16}-\mathrm{X} 29-\mathrm{Cys}_{46}-\mathrm{X} 2-\mathrm{C}_{49}\right)$, in which the three conserved cysteine residues $\left(\mathrm{Cys}_{16,46,49}\right)$, along with a conserved histidine resi- 


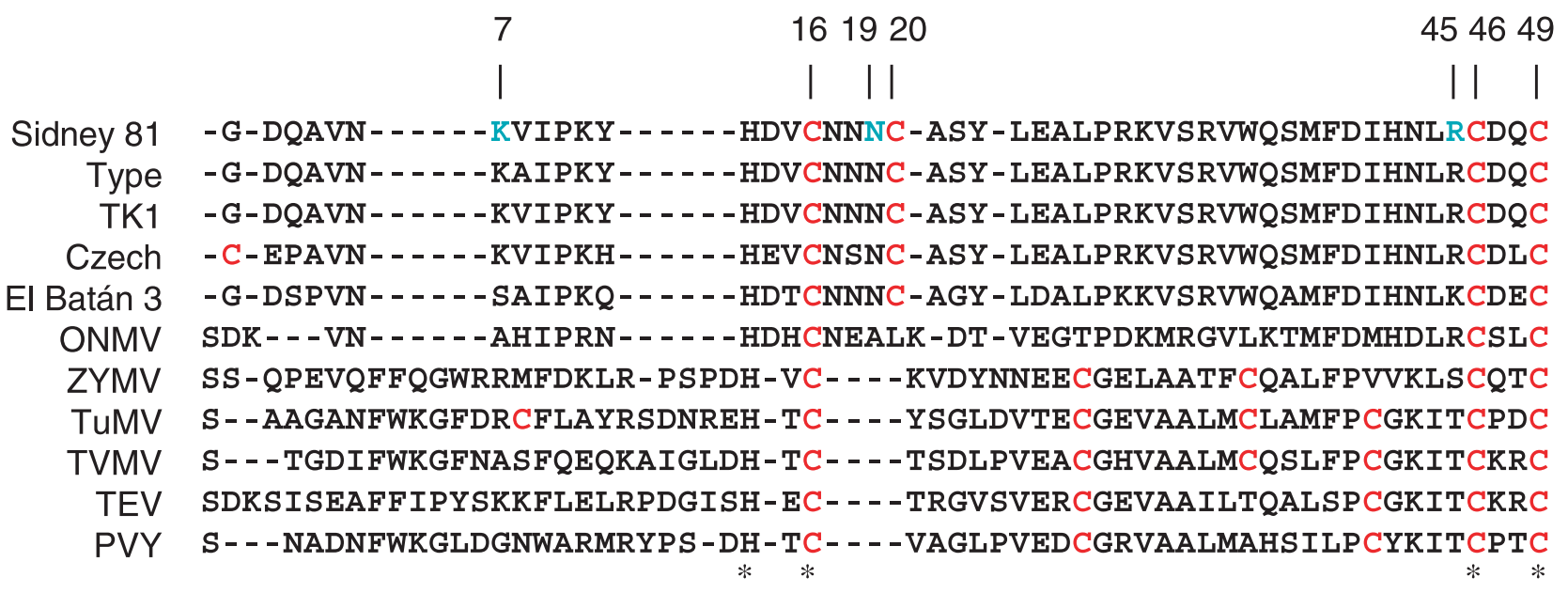

Fig. 1. Multiple alignment of the amino-proximal region of HC-Pro for five wheat streak mosaic virus (WSMV) strains (Sidney 81, Type, TK1, Czech, and El Batán 3), oat necrotic mottle virus (ONMV), and members of five species of the genus Potyvirus (zucchini yellow mosaic virus [ZYMV], turnip mosaic virus [TuMV], tobacco vein mottling virus [TVMV], tobacco etch virus [TEV], and potato virus Y [PVY]). Coordinates of amino acid substitutions introduced into Sidney 81 HC-Pro are indicated at the top. Cysteine residues are shown in red, and includes four Sidney 81 residues mutated to alanine (and also arginine for $\mathrm{Cys}_{20}$ ). Green denotes other Sidney 81 HC-Pro amino acid residues subject to substitution mutations. Asterisks $\left({ }^{*}\right)$ at the bottom denote a conserved histidine residue and three conserved cysteine residues constituting a zincfinger-like motif in WSMV HC-Pro (His $\left.{ }_{13}-\mathrm{X} 2-\mathrm{Cys}_{16}-\mathrm{X} 29-\mathrm{Cys}_{46}-\mathrm{X} 2-\mathrm{Cys}_{49}\right)$

due $\left(\mathrm{His}_{13}\right)$ in a favorable position relative to a cysteine residue (His-X2-C), constitute the key residues that interact with a zinc ion (Fig. 1). This same zinc-finger-like motif occurs in HC-Pro of oat necrotic mottle virus (ONMV), the tritimovirus species most closely related to WSMV [13], and is similar to that conserved among divergent potyviruses (Fig. 1). That mutations in the zinc-fingerlike motif of HC-Pro for both potyviruses and WSMV abolished vector transmission suggests that, despite very different modes of transmission by distinct vector taxa, at least some aspect(s) of the mechanism by which HC-Pro mediates vector transmission is similar among genera of the family Potyviridae. Although a fourth cysteine residue $\left(\mathrm{Cys}_{20}\right)$ could be mutated to alanine without affecting transmission by the wheat curl mite, substitution of this residue with arginine reduced vector transmission efficiency. If the hypothesis (wheat curl mite transmission of WSMV requires zinc bound to the zinc-finger-like motif of HC-Pro) is correct, then these observations suggest that $\mathrm{Cys}_{20}$ does not directly interact with the metal ion, but instead is likely part of a loop structure which tolerates some substitutions. Interestingly, ONMV
HC-Pro has leucine at this position rather than cysteine (Fig. 1), further suggesting that the zincfinger-like motif in tritimovirus HC-Pro does not require $\mathrm{Cys}_{20}$. To test the hypothesis stated above, non-transmissible WSMV HC-Pro mutants should be evaluated for zinc ion binding.

\section{Acknowledgments}

We thank Kathryn Stenberg for technical assistance. Mention of proprietary or brand names is necessary to report factually on available data; however, the USDA neither guarantees nor warrants the standard of the product, and the use of the name by USDA implies no approval to the exclusion of others that also may be suitable. This article is in the public domain and not copyrightable. It may be freely reprinted with customary crediting of source.

\section{References}

1. Atreya CD, Atreya PL, Thornbury DW, Pirone TP (1992) Site-directed mutations in the potyvirus HCPRO gene affect helper component activity, virus accumulation, and symptom expression in infected tobacco plants. Virology 191: 106-111

2. Atreya CD, Pirone TP (1993) Mutational analysis of the helper component-proteinase gene of a potyvirus: 
Effects of amino acid substitutions, deletions, and gene replacement on virulence and aphid transmissibility. Proc Natl Acad Sci USA 90: 11919-11923

3. Berg JM (1990) Zinc fingers and other metal-binding domains. J Biol Chem 265: 6513-6516

4. Choi I-R, French R, Hein GL, Stenger DC (1999) Fully biologically active in vitro transcripts of the eriophyid mite-transmitted wheat streak mosaic tritimovirus. Phytopathology 89: 1182-1185

5. Choi I-R, Stenger DC, French R (2000) Multiple interactions among proteins encoded by the mite-transmitted wheat streak mosaic tritimovirus. Virology 267: 185-198

6. French R, Stenger DC (2005) Complete nucleotide sequences of Agropyron mosaic virus and Hordeum mosaic virus support reciprocal monophyly of the genera Potyvirus and Rymovirus in the family Potyviridae. Arch Virol 150: 299-312

7. Govier DA, Kassanis B (1974) A virus-induced component of plant sap needed when aphids acquire potato virus Y from purified preparation. Virology 61: 420-426

8. Guo D, Merits A, Saarma M (1999) Self-association and mapping of interaction domains of helper component-proteinase of potato potyvirus. J Gen Virol 80: 1127-1131

9. Llave C, Martinez B, Diaz-Ruiz JR, Lopez-Abella D (2002) Amino acid substitutions within the cys-rich domain of the tobacco etch potyvirus HC-Pro result in loss of transmissibility by aphids. Arch Virol 147: 2365-2375

10. McNeil JE, French R, Hein GL, Baenziger PS, Eskridge KM (1996) Characterization of genetic variability among natural populations of wheat streak mosaic virus. Phytopathology 86: 1222-1227

11. Ruiz-Ferrer V, Boskovic J, Alfonso C, Rivas G, Llorca O, Lopez-Abella D, Lopez-Moya JJ (2005) Structural analysis of tobacco etch potyvirus HC-Pro oligomers involved in aphid transmission. J Virol 79: 3758-3765
12. Stenger DC, French R (2004) Functional replacement of Wheat streak mosaic virus HC-Pro with the corresponding cistron from a diverse array of viruses in the family Potyviridae. Virology 323: 257-267

13. Stenger DC, French R (2004) Complete nucleotide sequence of Oat necrotic mottle virus: a distinct Tritimovirus species (family Potyviridae) most closely related to Wheat streak mosaic virus. Arch Virol 149: 633-640

14. Stenger DC, French R, Gildow FE (2005) Complete deletion of Wheat streak mosaic virus HC-Pro: a null mutant is viable for systemic infection. J Virol 79: 12077-12080

15. Stenger DC, Hall JS, Choi I-R, French R (1998) Phylogenetic relationships within the family Potyviridae: Wheat streak mosaic virus and brome streak mosaic virus are not members of the genus Rymovirus. Phytopathology 88: 782-787

16. Stenger DC, Hein GL, French R (2006) Nested deletion analysis of Wheat streak mosaic virus HC-Pro: mapping of domains affecting polyprotein processing and eriophyid mite transmission. Virology 350: 465-474

17. Stenger DC, Hein GL, Gildow FE, Horken KM, French $\mathrm{R}$ (2005) Plant virus HC-Pro is a determinant of eriophyid mite transmission. J Virol 79: 9054-9061

18. Stenger DC, Young BA, French R (2006) Random mutagenesis of Wheat streak mosaic virus HC-Pro: noninfectious interfering mutations in a gene dispensable for systemic infection of plants. J Gen Virol 87: 2741-2747

19. Thornbury DW, Hellmann GM, Rhoads RE, Pirone TP (1985) Purification and characterization of potyvirus helper component. Virology 144: 260-267

20. Urcuqui-Inchima S, Maia IG, Drugeon G, Haenni A-L, Bernadi F (1999) Effect of mutations within the cys-rich region of potyvirus helper component-proteinase on self interaction. J Gen Virol 80: 2809-2812 